\title{
Research on corrosion protection of earthing device of electric transmission line
}

\author{
Xianri Wang ${ }^{1}$, Xinmin $\mathrm{Yu}^{2}$ \\ ${ }^{1}$ Power System and Automation, Fujian electric power economic research institute, FuZhou, FuJian, 350000, China \\ ${ }^{2}$ Structural engineering, Fujian electric power economic research institute, FuZhou, FuJian, 350000, China
}

\begin{abstract}
The selection of insulator is analyzed and studied in detail in combination with climate and pollution.In this paper, several comparison and selection schemes are studied in detail from the aspects of electrical performance, mechanical performance, economic performance and so on. Through the analysis of the whole life cycle and the combination of the actual situation of the project, the reasonable selection of insulators is carried out to make use of insulators to reach the optimal.
\end{abstract}

\section{Introduction}

The corrosion environment of transmission line mainly includes atmospheric corrosion, water corrosion and soil corrosion. Corrosion damage makes the life of the transmission line greatly shortened, especially for the transmission line in the corrosive environment, often can not reach its expected design life.In the design, construction, operation and maintenance of transmission lines in China, necessary protective measures are taken for transmission wires, overhead ground wires, towers, foundations and grounding grids, etc. The corrosion of wire, overhead ground wire, metal tools and tower structure is mainly atmospheric corrosion, while the corrosion of tower foundation and grounding net is mostly soil corrosion.

Due to the action of the surrounding environment, the material's properties decay and corrosion occurs. In the service process of natural environment, corrosion of metal materials is very common, which can be found in many fields of national economy and national defense construction. Especially for the corrosion of Marine engineering equipment and major infrastructure, due to the corrosion process is very hidden, usually not easy to find, once the corrosion damage, easy to lead to the occurrence of major safety accidents.As a result, so the study of atmospheric corrosion of metallic materials in, especially the common metals, new metal material corrosion characteristics and corrosion in the typical atmospheric environment law research and for the reasonable material selection, design corresponding anticorrosion scheme provides a powerful reference and guidance, to reduce atmospheric corrosion rate of metal materials, prolong its service life, reduce all kinds of loss caused by corrosion have extensive and important application value.

\section{Comparison of materials and economy of common grounding devices}

\section{1 overview of grounding device}

Power grounding device will power equipment of high accident situation of the current National People's Congress to guide, to ensure the safety of person and equipment of electric power grounding device including ground down lead and earthing body, generally adopts the round steel, flat steel, Angle steel and other steel materials for the ground down lead in exposed to the air is mainly the metal surface and the moisture in the air the electrochemical corrosion of salt. For grounding body buried in the ground, the main corrosion for the electrochemical corrosion of the soil, it is the soil $\mathrm{pH}$, stray current, chemical reaction, the resistivity and the action of microorganisms is great, oxygen and water is a key factor of soil corrosion due to soil medium has the characteristic such as diversity inhomogeneity, macro to micro cell corrosion and corrosion cell interaction. The degree of corrosion of different soil is generally different. The fine soil of clay and silt with poor drainage and aeration and high water retention capacity is more serious than that of coarse soil with good drainage and aeration.

\section{2 comparison of new grounding materials}

At present, new types of grounding include copper clad steel grounding, graphite based flexible grounding, ion grounding system, etc. In order to improve the anticorrosive performance of grounding materials, reduce the workload of replacement and maintenance, facilitate construction, reduce the excavation area, improve the

*E-mail: 33067934@qq.com 
effect of resistance reduction, protect the environment and reduce the cost of the whole life cycle, it is of great significance to carry out research on new grounding devices and adopt appropriate grounding materials according to local conditions.

(1) copper clad steel

Copper clad steel is a new type of composite grounding material with $99.9 \%$ electrolytic copper molecules uniformly covered on the steel core through continuous electroplating or continuous electrocasting process, and the copper and core molecules are closely combined.It has the advantages of high tensile strength, strong corrosion resistance, constant low resistance and good plasticity.

According to the requirements of technical conditions for copper clad steel materials for grounding in electrical engineering (Q/GDW 466-2010), the thickness of copper layer of all types of copper clad steel shall not be less than $0.25 \mathrm{~mm}$. On the basis of calculation, such as service life in 60 years, the annual corrosion rate is $0.25 / 60=$ $0.00416 \mathrm{~mm} / \mathrm{a}$, meet the soil corrosion resistance in table 5.21 level in II strong corrosion level requirements; Such as service life in 30 years, the annual corrosion rate is $0.25 / 30=0.00833 \mathrm{~mm} / \mathrm{a}$, meet the soil corrosion resistance in table 5.21 level in III strong corrosive level requirements.Therefore, the copper clad steel with a thickness of $0.25 \mathrm{~mm}$ thick copper layer is adopted to meet the corrosion resistance requirements of grounding bodies in corroded areas, which can be replaced after construction.

(2) graphite base flexible composite grounding body

Graphite has good electrical conductivity, and the graphite base flexible composite earthing made of it has the characteristics of corrosion resistance, easy construction, convenient transportation and environmental protection. At the same time, considering the rich reserves of graphite raw materials in China, low energy consumption in the production and processing process, and pollution-free products, more and more conductive products made of graphite began to be applied in the society. The grounding material has the following characteristics:

1) corrosion resistance: graphite can withstand acid, alkali, salt solution, seawater long-term erosion, can be used safely at $-200^{\circ} \mathrm{C} \sim 800^{\circ} \mathrm{C}$; Carbon nanotubes: high conductivity, strong corrosion resistance;High strength fiber: resistant to heat, fire, acid, alkali and organic solvents.No electrolytic reaction occurs under the action of stray current.

2) softening: can be pulled, twisted, folding, pressure, can be rolled, the surface of the rough form of fine holes, and the soil bite adhesion, creep with the soil, do not break off, do not produce air interface, expand and soil contact surface, laying can choose mud backfill, drag reducing agent, antifreeze, etc.;

3) dynamic and thermal stability: current dispersion, large section to reduce the current density; The material has large specific heat capacity and strong heat absorption ability. Soil moisture penetrates into the grounding body and gasifies at $100^{\circ} \mathrm{c}$ to absorb a large amount of heat. Resistance to oscillation shock: $127.5 \mathrm{ka}$, $120 \mathrm{~s}$; Short circuit shock resistance: $25.6 \mathrm{ka}, 150 \mathrm{~ms}$;

4) non-magnetic, reduce the inductance;

5) improve the impact utilization rate: the common magnetic material skin effect is serious, the material utilization rate is low;28 round graphite material, non-magnetic to alleviate its high frequency skin effect, plus special process structure, resulting in the material utilization rate of more than $80 \%$.

6) easy construction: coiled, convenient transportation;Small amount of excavation, can be serpentine excavation to avoid rocks, trees, etc., simple backfill, compression connection, no need for welding, no need of power welding machine and other site requirements.

Figure 2.2-2 graphite base flexible composite earthing

(3) stainless steel composite materials

Stainless steel composite material is made up of two parts: high quality carbon steel special wire and special stainless steel tube. The base material of stainless steel composite material chooses high-quality carbon steel, the base material of hot dip galvanized round steel is ordinary carbon steel, the physical properties of high-quality carbon steel are much better than ordinary carbon steel, especially the material resistivity is low, strong impact resistance. The outer layer is coated with a layer of stainless steel composite material, which has good combination with the inner core and can effectively prevent skin warping, cracking and other phenomena during installation, and has good corrosion resistance.

(4) ionic grounding electrode

Ion grounding to cover an area of an area small, low construction difficulty, drag-reducing effect lasting stability for technological breakthroughs, such as its unique ion slow-release technology and the corrosion resistance of the grounding resistance reduction effect is improved and the best value tends to be stable, suitable for different geological conditions, especially suitable for all kinds of high grounding requirements, grounding engineering difficult place, superior performance and low cost. The product consists of three parts: metal electrode unit for anti-corrosion treatment, compound back filler with high resistance reduction effect and soil pretreatment agent. This product has the characteristics of easy installation, short length of grounding body, less excavation, no water demand during installation, corrosion resistance, stable grounding resistance and high safety.

Under the condition of the same soil resistivity, the length of ion grounding electrode is shorter than that of the conventional galvanized round steel grounding electrode.

\section{3 economic comparison}

The comparison table of galvanized round steel, graphite base flexible composite grounding body, copper clad steel, stainless steel composite material, ionic grounding electrode and other grounding materials is as follows. 
Table 1. comparison table of grounding materials

\begin{tabular}{|c|c|c|c|}
\hline Project & Basic program & Production & Maintenance \\
\hline $\begin{array}{l}\text { Galvanized round } \\
\text { steel }\end{array}$ & $\begin{array}{l}\text { Box }+ \text { ray }+ \\
\text { grounding module }\end{array}$ & $\begin{array}{l}\text { The production process } \\
\text { is mature and there are } \\
\text { many manufacturers }\end{array}$ & $\begin{array}{l}\text { Generally, it needs to be } \\
\text { replaced after several years } \\
\text { of easy operation.Low cost, } \\
\text { not easy to steal }\end{array}$ \\
\hline $\begin{array}{l}\text { Graphite base } \\
\text { flexible composite } \\
\text { earthing }\end{array}$ & $\begin{array}{l}\text { Box }+ \text { ray }+ \text { graphite } \\
\text { cloth }\end{array}$ & More manufacturers & $\begin{array}{l}\text { Maintenance free, up to } 30 \\
\text { years; }\end{array}$ \\
\hline Copper coated steel & $\begin{array}{l}\text { Box }+ \text { ray+vertical } \\
\text { grounding }\end{array}$ & $\begin{array}{l}\text { The production process } \\
\text { is mature and there are } \\
\text { many manufacturers }\end{array}$ & $\begin{array}{l}\text { Maintenance free, up to } 30 \\
\text { years; High cost, easy to } \\
\text { steal. }\end{array}$ \\
\hline $\begin{array}{l}\text { Stainless steel } \\
\text { composite }\end{array}$ & $\begin{array}{l}\text { Box }+ \text { ray } \\
+ \text { grounding module }\end{array}$ & $\begin{array}{l}\text { Production process is } \\
\text { more mature, fewer } \\
\text { manufacturers }\end{array}$ & $\begin{array}{l}\text { Maintenance free, up to } 30 \\
\text { years;No theft value }\end{array}$ \\
\hline $\begin{array}{l}\text { Ion grounded } \\
\text { electrode }\end{array}$ & $\begin{array}{l}\text { Box }+ \text { ion } \\
\text { grounding electrode }\end{array}$ & Fewer manufacturers & $\begin{array}{l}\text { Maintenance free, up to } 30 \\
\text { years }\end{array}$ \\
\hline
\end{tabular}

Can be seen from the table above, soil resistivity is less than $2000 \Omega$. M, galvanized round steel LCC cost minimum, soil resistivity is greater than or equal to 2000 $\Omega$. M, flexible graphite matrix composite earthing body in LCC cost minimum, therefore, the soil resistivity is less than $2000 \Omega$. When $\mathrm{m}$ galvanized round steel, is recommended for the soil resistivity is greater than or equal to $2000 \Omega$. M in flexible graphite matrix composite is recommended for the grounding system.

\section{3 conclusion}

Because the process of transmission line corrosion is very subtle, it is usually difficult to find, once the corrosion damage, it is easy to lead to the occurrence of major safety accidents.Therefore, the reasonable selection of materials and the design of appropriate anti-corrosion schemes have extensive and important application value for reducing the corrosion rate of metal materials, prolonging their service life and reducing various losses caused by corrosion.

\section{References}

1. Henriksen J. Corrosion of electronics: a handbook based on experiences from a Nordic research project[M]. Korrosionsinstitutet, 1991

2. Azevedo C R F, Cescon T. Failure analysis of aluminum cable steel reinforced (ACSR) conductor of the transmission line crossing the Parana River $[\mathrm{J}]$. Engineering Failure Analysis, 2002, 9(6): 645-664

3. Hou W, Liang C. Eight-year atmospheric corrosion exposure of steels in China[J]. Corrosion, 1999, 55(1): 65-73.

4. El-Mahdy G A, Nishikata A, Tsuru T. Electrochemical corrosion monitoring of galvanized steel under cyclic wetdry conditions[J]. Corrosion Science, 2000, 42(1): 183-194

5. Neufeld A K, Cole I S, Bond A M, et al. The initiation mechanism of corrosion of zinc by sodium chloride particle deposition[J]. Corrosion Science, 2002, 44(3): 555-572 